\title{
ORIENTALISM IN THE AMERICAN AND BRITISH MEDIA EDITORIALS: ORIENTALIZING ISLAM AND ISLAMISTS IN THE COVERAGE OF THE EGYPTIAN REVOLUTION AND ITS AFTERMATH (2011-2018)
}

\author{
Ayyad ECHINE ${ }^{1}$ \\ ${ }^{1}$ PhD, Department of English, Faculty of Letters and Humanities, Ibno Zohr University, Agadir, Morocco
}

Article DOI: https://doi.org/10.36713/epra7043

DOI No: 10.36713/epra7043

\begin{abstract}
The Arab revolutions of 2011 and their aftermath produce a myriad of political contexts that triggered much coverage in the Western media. This study draws on Edward Said's postcolonial critical model of Orientalism (1978) to locate Orientalist tropes in Western media editorials that cover the revolution and its aftermath in Egypt (2011-2018). It discusses the ideological manipulative functions of the media to see if they are utilized to provide a coverage that emanates from the classical Orientalist frames when reporting about the revolution's participants -Muslims/Islamists. Using critical discourse analysis, this thesis examines the editorial narratives $(n=101)$ of four highly read US and British newspapers: The New York Times, The Washington Post, The Telegraph and The Guardian. The thesis outlines evidence that suggests that the selected media's representation of the revolution's participants is imbued with the ideology of Orientalism: Islam, political Islam, and the Muslim Brotherhood are reported through stereotypical lenses that posits them as an antithesis of the modern Western society and its values.
\end{abstract}

KEY WORDS: Orientlaism, The Egyptian revolution, Islam and Islamists, CDA, Editorials

\section{INTRODUCTION}

The Arab world has seen dramatic political changes since December 2010 when the Jasmine revolution was triggered in Tunisia. The International news media swiftly responded to that revolution which subsequently inspired people in other Arab countries, such as Egypt, to revolt against their ruling regimes. While following the news media coverage of this critical period, one realizes that Edward Said's critical model as exposed in Orientalism, a founding text of postcolonial theory, comes back today with vibrancy and resonance to account for the nature of such media coverage. Many critics argue that the rise of the Arab Spring calls an end to postcoloniality as a condition and mode of ideology formation, and that the line between 'East' and 'West' is blurred (Dabashi, 2012). Other critics went further as to argue that neo-Orientalists such as Bernard Lewis and Samuel Huntington are silenced by the loud voices of the protests in Tunisia, Egypt and Libya (Ould Brahim, 2012). On the other hand, other critics argue that even when the West refers to the Arab revolutions as 'Arab awakening' or "Arab spring" it represents Arabs with the same old Orientalist terminology (El-Mahdi, 2011; Khouri, 2011). Along the same line, this study suggests that Orientalist discourse is the driving narrative which underlies Western media coverage of the Arab spring.

Thus, two different arguments emerge as an outcome of what happened in the Middle East: One calls an end to Orientalism while the other presents Orientalist rhetoric as a persistent discourse that has been neither modified nor metamorphosed when reporting the Arab uprisings of 2011. This study intends to evaluate both positions and interrogate whether or not Orientalist rhetoric is present in the New York Times, the Washington Post, the Guardian, and the Telegraph editorials' portrayal of Islam and Islamists in the Egyptian uprising and its aftermath.

Broadly, editorials are media tools for telling news. However, they are entitled to transcend this simple undertaking. Newspapers' editorials present news events and provide the news evaluation. They 
also have a persuasive social function in the sense that they tend to influence the social cognitions of their readers (Van Dijk, 1991). Locating an ideological rhetoric such as Orientalism in media texts necessitates considering texts with heavy ideological connotations. Evidently, news articles will not do in this regard but editorials are much relevant for such academic scrutiny. An Editorial is defined as "a corporate voice or position of a media organization on any given issue of public interest" which is also known as the leader (Azeez, 2018 , p.1) or a leading article in a newspaper. The editorial or leader is very influential as it leads its readers to take decisions on the issues being discussed, and/or kick against an idea or policy (Duyile, as cited in Azeez, 2018, p.2).

The Western news media has been faithfully committed to the propagation of the Orientalist discourse when covering Arabs and/or Muslims in past critical periods. The Gulf war 1991 and the invasion of Iraq 2003 are cases in point. Therefore, I assume that the selected media's coverage of Islam and Islamists in the Egyptian revolution and its aftermath does not sing on a different tune. Accordingly, my hypothesis is that this coverage is characterized by a Manichean division that conceives of the world as two distinctive entities: the Orient vs. the West, Us vs. Them. Accordingly, the research questions of this paper are as follows:

a. Is the Orientalist understanding of Islam and Islamists reflected in the editorials' coverage of the revolution?

b. What are the most frequent Orientalistbased themes, if there are any, in the coverage?

Edward Said's Orientalism (1978) forms the theoretical background of this study. His critical model provides an exhaustive analysis of Orientalist narratives and renders visible how such discourse enables the execution of authority and domination over the Orient (p.55).

This study will examine the extent to which the sample (editorials written by the aforementioned newspapers between 2011 and $2018(\mathrm{n}=101))$ reflects Orientalist conceptualizations of Islam and Islamists in the context of the revolution. One main area in critical media studies will be targeted: critical discourse analysis (CDA). Norman Fairclough's CDA (1989, 1995a, 1995b, 2003) is borrowed in this investigation. His analytical strategies, textual and discursive, will be made use of for a better qualitative analysis of the editorials. Excerpts from the editorials will be stated through the analyses.

The fact that Britain and its past colonial ambitions were more often than not referred to in postcolonial writings makes scrutinizing the British media narratives so pertinent in the research scope of this study. Likewise, choosing the U.S. media coverage of the revolution in Egypt to trace an ideological discourse such as Orientalism can be easily justified. The term neo-Orientalism for example has been coined basically to criticize the American neo-colonial agenda and its "war-on-terror" in the Middle East (Altwaiji, 2014, p.316). In such a way, the U.S. and its experts on the Middle East (neo-Orientalists) have inaugurated "a new academia of Orientalism" (p.316).

\section{REVIEW OF LITERATURE}

A large and growing body of literature has investigated the nature of Western media narratives about Islam and Arabs. The review below outlines how these Easterners, in different contexts, have been presented to the audience.

Edward Said's (1981) Covering Islam provides indepth analysis of how Islam and Arabs are "covered, covered up, portrayed, characterized, analyzed" by the Western Media. Said argues that the way Islam is covered is a "one-sided activity that obscures what "we" do" (by "we", he means the West), "and highlights instead what Muslims and Arabs by their flawed nature are" (Said 1981: xxii). The American media has been always selective when working on media releases that deal with Arabs and Islam in the sense that this media chooses not to report about Islam and Arabs but in a negative way. It can be inferred from such coverage that "the true nature of Islam is not allowed to be known to others" (Saeed, 2007).

\section{The Western Media Selectiveness in Reporting Arabs and Islam}

It has been argued that the interest in delving into the way the "west" reports about the "rest", namely Muslims, started ages ago but increased noticeably after events such as the Rushdie affair, the Gulf war and the $9 / 11$ bombings (Saeed, 2007) though, basically, the ideological construction of the West and the "Other", according to Said (1978) "can be traced back to the expansion of Western imperialism".

The American media tends always to cover up and underreport certain issues that would help in providing a different image about Islam and Muslims, and opt instead for emphasizing the traditional Orientalist images that the Westerners adopt centuries ago to define Islam (Said, 1981). Muslims" "sense of justice, their history of oppression, their vision of their own society seem irrelevant" (p.8). Likewise, little knowledge about the whole civilization of Islam; its literature, history and sociology has not prevented Western experts on Islam from generalizing about the "Islamic mind-set" (p.14). For Said, such 
generalizations have been confined to and highly welcomed by the media that presents Islam before most Americans just when it is mainly connected to newsworthy issues such as oil and terrorism (1981).

In the same vein, Said (1981) conceives of the media a "cultural apparatus" from which Europeans and Americans derive their consciousness (p.44). For said (1981), through ignorance, cultural hostility and racial hatred, the Western audience is drifted far from the true nature of Islam (p.163). Accordingly, the Western audience is always ready to accept the American homogenous coverage of Muslims because the latter are always depicted as the opposite of the West (Saeed \& Drainville, as cited in Saeed, 2007, p.453). To confirm this argument, Saeed (2007) evokes the publication of caricatures of Prophet Muhammad (PBUH) by a Danish newspaper to argue that such publications suggest that the prophet was a terrorist and Islam is a root of terrorism.

\section{Homogenizing the 'Rest'}

Islam and Muslims are mostly portrayed as a single entity that is always positioned opposite the West (Akbarzadeh \& Smith, 2005; Poole, 2002). The issue of terrorism is worth discussing in this regard for the media under review tends always to extend terrorism to all Muslims on earth. Whenever a violent incident committed by Muslim-named individuals, the whole Muslim society will be accused of terrorism. Osama Bin Laden, for example, is considered a representative of all Muslims rather than being a criminal (Nurullah, 2010). Besides, the British media, via its inaccurate and value-loaded language, calls Osama bin Laden a "Muslim fanatic", a "Muslim fundamentalist" and a "Muslim extremist and terrorist", and Islam a religion of violence and irrationality (Conte, 2001, para.3). Accordingly, the Western media is providing a version of Islam which can be referred to as "mass media Islam" that contains only acts of a violent minority while the peace-loving majority of Muslims is put outside the scope of the same coverage (Abdallah \& Rane, 2007, p.7-8).

The Western motion picture and visual media are used as vehicles through which biases and stereotypes about the Arabs and Muslims are disseminated. Reel bad Arabs: How Hollywood vilifies a people is Jack Shaheen's (2003) indispensable reference tool to learn about how films abuse the Arab individual. Shaheen provides a thorough and exhaustive analysis of 900 Hollywood movies portraying Arabs. He demonstrates how Hollywood movies viewers are made to believe that all Muslims are Arabs and all Arabs are Muslims. Shaheen (2003) sees that Hollywood movies' repetitive negative portrayal and stereotypes influence even Arabs and
Arab-Americans and make them perceive themselves as bad people. Therefore, for Shaheen, real Arabs will never be known (2003). Shaheen's analysis of hundreds of American movies shows how the Arab character is disgracefully called "bastards", "pigs", "camel-dicks", "jackals", "rats", "ragheads", "buzzards of the jungle", and "son of whores" (p.11).

Conversely, in reality, the majority of Arab people have never slept under a tent or ridden a camel (2000). In this regard, Arti (2007) tells us that there has never been an intention to represent the true nature of Arabs. For him, intensifying the Arabs' stereotypical images serves the U.S. political and cultural interests in the region which is motivated by the American imperial ambitions (2007).

The Portrayal of Arabs in Hollywood films evolves and takes different shapes through time. Brian Edward (2001) has uncovered a direct link between the end of the Cold War and a shift in Hollywood, leading to Arabs and Muslims playing the 'enemy role' as a replacement for communism. Edward concludes that the negative stereotype of the Middle East, which is designated as 'Hollywood Orientalism', is still persistent and insidious (2001, p.13).

The media under scrutiny underreports the real teachings of Islam by rendering individual behaviors representative of the whole religion of Islam. The same media makes it difficult for their audience to differentiate between real Islam and few Muslims' behavior (Nurullah, 2010, p.1027-1028).

\section{Review of Theory}

This investigation utilizes Edward Said's postcolonial critical model to make sense of the selected media texts. Orientalism was initially defined by Said "as a style of thought based upon an ontological and epistemological distinction made between the Orient and most of the time the occident" (Said, 1978, p.2). It is "a Western style for dominating, restructuring, and having authority over the Orient" (p.3). Said argues that the Orientalists divided the world into two parts; the East and the West, the Occident and the Orient, the civilized and the uncivilized. Their writings corrected and penalized the East "for lying outside the boundaries of European society" (p.67). In those Orientalist productions, the Oriental, according to said, is always defined within 'dominating frameworks'. It is "depicted as something one judges (as in a court of law), something one studies and depicts (as in a curriculum), something one disciplines (as in a school or prison), something one illustrates (as in a zoological manual)" (p. 4).

Said (1978) makes clear the idea that the West implements a binary oppositional method that permits 
it to define itself by traits that the East does not reflect. When the European is a reasoner, accuracy lover, mature, normal, rational and virtuous, the Oriental is irrational, childish, different and gullible (p. 40). For Said "the Orient has helped to define Europe (or the West) as its contrasting image, idea, personality, experience." (p.1-2). In other words, the Western identity is defined from within its juxtaposition against the Orient. Therefore, Orientalism is not only about the Orient but it is also about the West itself. Moreover, the Western depiction of the 'Orient' as the 'Other' was very crucial to understand the 'self', and this "constituted an enormously powerful cultural form, or what Gramsci identified as 'hegemony" (Rushworth, 2012).

\section{METHODOLOGY}

Sampling, Newspapers selection and editorials

The newspapers chosen for analysis are The New York Times, The Washington Post, the Guardian and the Telegraph. These papers are among the most influential broadsheets with a high circulation rate. They have international far reached readers who are often fairly affluent and educated (Rogers, 2018).

The broadsheets editorials, compared with tabloids or news articles, provide exhaustive coverage with a high degree of analytical competencies. In this way, as this investigation examines an ideological rhetoric, editorials are found to be the best unit of analysis - sample - because their influential and ideological nature suits perfectly the discourse in question.

The case study in this paper is the 2011 Egyptian revolution and its aftermath (2011-2018). This study scrutinizes the American and the British print media coverage of this uprising. It aims at investigating the nature of the coverage and to see if the editorials reflect Orientalist modes of thought in their portrayal of Islam and Islamists. The number of editorials that cover the Egyptian revolution and aftermath (2011-2018) varies according to each newspaper: The New York times $(n=43)$, The Washington Post (21), The Guardian $(n=26)$, and The Telegraph $(\mathrm{n}=11)$.

\section{Critical Discourse Analysis}

Critical discourse Analysis is conceived of as a branch of critical studies that focuses on social problems and power dynamics that involve instances of domination and resistance (Chouliaraki and Fairclough, 2010). What distinguishes this method is that it scrutinizes discourse in context rather than dealing with texts as isolated linguistic items (Fairclough, 1992, 1995; Van Dijk, 1997a). Therefore, textual analysis as suggested by CDA critically analyzes subjects and power relations within discourse in specific contexts.

Literature on CDA shows that there have been many attempts to systematize the functions of this approach. To name but a few, Fairclough (1992a, 2001) and Wodak's (1996) focus on textual analysis; and Van Dijk's (1997) and Gee's $(1999,2005)$ focus on social variables such as context, power relations and ideology. Fairclough and Wodak (1997) outlined eight main principles of CDA that summarize few of the notions mentioned above. The first is that CDA, beyond its focus on language use, addresses social problems in the sense that it renders visible power relations which are frequently hidden in society (1997). The second is that power relations are discursive; that is they are exercised through discourse (1997). The third is that language use or discourse contributes in the transformation of society and culture, and therefore, power relations (1997). The next principle considers discourse a work of ideology, and to better understand how ideologies are produced through discourse an analysis of discursive practice (text production, consumption and effect) in addition to textual analysis have to be addressed (1997). Another principle emphasizes the importance of historical context in the understanding of discourse (1997). The next principle highlights the fact that the link between text and society is mediated (1997). The mediated relationship between text and society always follows "an order of discourse" (Fairclough, 1992a), which is defined by Fairclough as "totality of discursive practices of an institution and relationship between them" (1993, p.138). The next principle is that CDA goes beyond textual analysis and encompasses as well interpretation and explanation of intent (Fairclough \& Wodak, 1997). Ultimately, discourse, from the perspective of critical discourse analysts, is a social action that aims at uncovering opaqueness and power relationships (Fairclough \& Wodak, 1997).

The present study adopts Fairclough's approach of CDA. The theoretical considerations outlined above are operationalized by Fairclough (1992a, 1995a) who guides textual analytical on: 1) vocabulary (how words function to show ideology), 2) transitivity (agency patterns in a text), 3) modality (conveying certainty and authority), 4) presupposition (unchallenged implicit assumptions), 5) scale of presence in a text; absent / presupposed / backgrounded / foregrounded) and many other tools of analysis. This investigation draws on some of these tools to answer the research questions and simultaneously explains each analytical tool within text analysis. 


\section{The Egyptian Revolution Context and Western Media Attention}

The uprising in Egypt was part of a series of movements against authoritarian leaders that are called 'the Arab Spring' by the world media. These demonstrations climaxed in Tunisia on the last days of the year of 2010 and later swept other countries among which is Egypt. On January 25, 2011, Egyptian activists took to the street and headed to their gathering location Tahrir Square to revolt against a long-standing corrupt regime led by President Hosni Mubarak and his associates, and to call for a democratically elected government that would replace Mubarak's repressive regime. The security forces' initial reactions to the protests were banning public gatherings, using tear gases to disperse the rebels, blocking the internet services, as they were of great help for the protests to organize their street mass protest, and setting up a curfew (Abushouk, 2014). Unwilling to leave office, Mubarak's regime made concessions like appointing Omar Suleiman as vice president and giving him orders to start negotiations with political forces in the country, and urging the protests to withdraw from the streets. Mubarak's concessions to moderate his power grab were not the ultimate goal the rebels were striving for, yet they applauded to Mubarak's departure on February 11, 2011 though the administration was left in the hands of a military council (Abushouk, 2014).

Among the reasons behind examining the coverage of the Egyptian revolution's aftermath is the fact that the Egyptian revolution did not finish or satisfies its ambitions with the ousting of Mubarak. Egypt has gone through years of turmoil and transition after Mubarak relinquished power; a transition that has been subject to up-to-the-minute groundbreaking coverage from the international media, namely the Western.

The initial reading of the editorials suggests that key events that characterize the Egyptian revolution were over-reported by Western media. The most alarming one for the West is when "the Muslim Brotherhood ${ }^{1}$ wins nearly half the seats in multi-stage elections for the first post-Mubarak parliament, while ultraconservative Salafi Islamists take another quarter" sixteen months after the military took over on the ouster of Hosni Mubarak (news24, 2018). Four months later, The Muslim Brotherhood's candidate Mohammed

\footnotetext{
${ }^{1}$ The Muslim Brotherhood, or al-Ikhwān al-Muslimūn in Arabic, is the world's oldest Sunni revivalist organization in the Arab world. (Insidearabia.com, 2019)
}

Morsi defeated Ahmed Shafiq, Mubarak's last prime minister, and won the elections with $51.7 \%$ and took office on June 30, 2012 as Egypt's first freely elected president (2018). Morsi's policies were severely criticized by both the Egyptian civilians and political parties for the greater powers Morsi decreed for himself. Subsequently, On Morsi's anniversary in office, June 30, 2013, the Egyptians took to the street to demand Morsi's resignation; a demand that was supported by the military that, four days later, announced Morsi's removal and installed an interim president. The announcement was made by Chief General Abdel Fattah Al-Sisi on 3, July, 2013 (news24, 2018).

Subsequent violent incidents swept Egypt after what has been considered a military coup against Morsi; More than 600 people, mostly Morsi supporters, are killed and Islamists reacted back violently. An Egyptian court considered the Brotherhood a banned group that was later designated a terrorist organization by the government. Later, Morsi and 682 other people were accused of charges of inciting violence and of the killing of policemen for which, according to the court, they deserved death penalty (news 24,2018 ). Many other incidents were incessantly reported by world media such as Al-Sisi electoral victory in May 2014 and the dismissal of murder charges against Mubarak in November 2014, for these events go against the ambitions on which the 2011 revolution was grounded.

\section{RESULTS AND DISCUSSION Islam and Islamists: Threatening and Fearful. \\ The Foregrounding of Islam, the Muslim Brotherhood, Iran, and Israel.}

In the preface to the 2003 edition of Orientalism, published shortly before his death, Edward Said writes that:

Bookstores in the US are filled with shabby screeds bearing screaming headlines about Islam and terror, Islam exposed, the Arab threat and the Muslim menace, all of them written by political polemicists pretending to knowledge imparted to them and others by experts who have supposedly penetrated to the heart of these strange Oriental peoples over there who have been such a terrible thorn in "our" flesh. (p. xv)

Clearly, Said's words are echoed in the way Islam is envisaged and reported nowadays. The coverage of the 2011 Egyptian revolution is one of those contexts where Islam and political Islam are presented and framed as a threat. On the one hand, the fearful nature of Islam is claimed to be acknowledged by Egyptians themselves. It is suggested that they are cautious and 
worried about any involvement of Islam and the Muslim Brotherhood in the Egyptian revolution. The $N Y T, W P, T$ and $T h e$ s s coverage of the issue reflects classic Orientalist trope of Islam being violent, fearful and threatening. In the context of the elections following Mubarak's ousting, The NYT and The $G$ write:

1) "The young protesters ... worry their demand for democracy could be hijacked by ... the Muslim Brotherhood."(NYT, "Egypt's Unfinished Revolution", 24 March, 2011)

2) "Leaders of the democratic uprising were also expressing anxiety about the strong showing by Islamist parties."(NYT, "Egypt's Vote", 01 December, 2011)

3) Most Egyptians have no interest in swapping Mubarak's secular dictatorship for a religious one."(NYT, "Egypt's Vote", 01 December, 2011)

4) "They [the ordinary Egyptians] are in no hurry to replace a repressive secular regime with a repressive religious one." $G$, “Cairo protests: The west has a duty to nurture democracy", 06 February, 2011)

The exerpts above, namely 1 and 2 , show that the Egyptians, who are referred to as a group, are wary of and anxious about Islamists' parties, namely the Muslim Brotherhood. The fact that the Egyptians are afraid their democratic demands might be hijacked by Islamists suggests that democratic reforms are away from being realized and sought by Islamists or by Islamic ruling. This statement clearly positions Islam as the opposite of democracy. Moreover, as suggested in excerpts 3 and 4, the negative portrayal of Islam and Islamists is intensified in the sense that dictatorship is reported to be favoured over Islamic ruling by Egyptians. Such reports suggest that Islamic ruling, if practiced, will be at best worse than autocratic regimes.

Here, the editorials writers are presupposing that "leaders of the democratic uprising", "most Egyptians", and the "young protesters who made the revolution happen", though they belong to a country where Muslims make up $90 \%$ of the population, hold a negative attitude towards Islamic ruling. What makes of these scripts mere presuppositions is the fact that Egyptians are referred to as a group while there is a lack of a direct voice in the coverage; not a single Egyptian was given the opportunity to confirm or negate the stories. Besides, the fact that the Islamic party won the elections afterwards refutes and proves the above mentioned coverage to be the journalists' own evaluation, rather than the Egyptians' authentic version of the story. Relatedly, presuppositions for Fairclough (2003) have an ideological significance, and since they cannot be challenged or defied, they become a part of a dominant ideological convention that, in this case, emphasizes a fearful aspect of Islamists and their ruling.

On the other hand, Islam is reported to be deemed fearful by the West, namely the U.S., Britain and Israel. Early in its coverage of the revolution, The $W P$ writes:

5) "Egypt has been a vital ally of the United States, and a potential change of regime there is frightening to many in Washington, especially given the strength of the country's Islamist movement."(WP, "Egypt's unstable Regime", 25 January, 2011)

While religion, namely Islam, was clearly absent from the protests, the selected editorials present Islam, the Muslim Brotherhood and political Islam at large as a key to understand the events that swept Egypt. The $W P$ announces, from the very beginning, that a loss of Egypt as a faithful ally under Mubarak's rule is frightening, and what makes it more frightening is the existence of a strong Islamic movement in Egypt. Thus, Egypt under Islamic law is fearful to the West. Here, Islamists are "foregrounded" as the strong available alternative to Mubarak's regime in Egypt. The same idea is foregrounded and reported by The Guardian that presents Islamic ruling a fearful outcome as far as the Western leaders are concerned:

6) "In place of Mubarak and men of his ilk, western leaders fear the rise of militant Islam, the ascendancy of groups such as Egypt's Muslim Brotherhood, and a general loss of influence and stability in the Middle East." $(G$, "Mubarak's dictatorship must end now", 30 January, 2011)

It is suggested in the excerpt above that the loss of a faithful ally in Egypt will be followed by the rise of militant Islam and the Muslim Brotherhood with which the West will lose its influence in the Middle East. This is to say that the absence of Western influence in the Middle East will lead to instability in the region, as the West is implicitly presented as peace and stability promoter. Accordingly, Islamic ruling or the Muslim Brotherhood will promote the opposite image if it replaces Mubarak in Egypt. The Foregrounding in this case helps the media to highlight the differences between Islam and the West; the West as able to promote stability in the Middle East and Islamic ruling as fearful and chaotic. Moreover, the Muslim Brotherhood is made to appear in the media as a homogeneous whole, which is a strategy routinely followed to portray Islam as a monolithic religion. However, as Peter Mandaville stated, "Islam is not a 
monolith, neither is political Islam" (Mandaville, 2013, p. 238),

The 'foregrounding' of Islam and the Muslim Brotherhood is accompanied by the 'backgrounding' of other groups that played a vital role during the revolution. In his analysis of the social actors in the Egyptian revolution, Telci (2011) provides an exhaustive micro level analysis of positions of social actors in the Egyptian revolution and speaks about civil society organizations and groups that actively participated in the revolutionary demonstrations. In the context of this investigation, these social actors receive scant attention in the selected editorials under study. It should be noted here that the selected media foregrounded the Islamists and backgrounded other social actors before the ousting of Mubarak and the ruling of Morsi, the Muslim Brotherhood candidate, as the elected president of Egypt. Foregrounding and backgrounding, therefore, are tools to put the agenda setting function of the media into practice. It is useful to recall that media gate keepers cut down billions of available messages and diffuse only the messages that suit the paper's editorial line (shoemaker's, 1991).

Accordingly, 6 April Youth Movement, which was one of the most influential actors of the Egyptian revolution (Telci, 2011), received scant coverage by the selected papers during the revolution, but it was referred to, when its leaders are already serving prison sentences in Asisi's prisons, in 2013 (see "Who Will Be Left in Egypt?", the NYT, 12, September 2013, and "Egypt: back with a vengeance", the G, 25, December 2013) and in 2014 (see "Egypt's jailing of democracy activists shows how far it has backtracked", the WP, June 2014, and "Political Executions in Egypt", the NYT, 28, April 2014). One singular mention of the 6 April movement as a well-organized group during the revolution appeared in 2011 in The WP (see "Misconceptions about the Egyptian crisis", WP, 31, January 2011). Meanwhile, the Islamists and the Muslim Brotherhood are foregrounded and mentioned in most of the editorials.

Likewise, Kefaya (an Egyptian word for "enough"), which is the Egyptian Movement for Change, and that "has become one of the most visible oppositional organization that held systematic and consistent demonstrations throughout the country during, especially in the last decade of, the Mubarak Era" (Telci, 2011, p.179), was mentioned once by The Guardian in the whole sample $(n=101)$ (see "Mubarak's dictatorship must end now", the G, 30, January 2011) though this group "used every opportunity to support Egyptian people's will and quest for democracy, human rights and more importantly termination of the Mubarak regime" (Telci, 2011, p.179).
Equally important, the National Association for Change (NAC) and its leader Muhammed El-Baradei were not given comparable consideration as given to the Muslim Brotherhood in the coverage. The NAC led by Muhammed El-Baradei, the former President of the International Atomic Energy Association, launched opposition campaigns to bring Mubarak era to an end and was among the first movements that offered full support to the Egyptian protesters (Telci, 2011). However, the NAC and its leader were infrequently referred to and made ineffective compared to the Islamists. This argument is well illustrated in the following excerpt taken from The NYT editorials:

7) This [preparing for elections] is made far more complicated by the fact that Egypt has few opposition groups - the result of $\mathrm{Mr}$. Mubarak's 30 years of authoritarian rule. The best organized is the banned Muslim Brotherhood. Mohamed El-Baradei, the former top nuclear inspector for the United Nations and a Nobel laureate, is eager to lead. (NYT, "Beyond Mubarak", 01 February, 2011)

In the excerpt above, the Muslim Brotherhood is placed in a foregrounded position which emphasises it as the best organized political group in Egypt, while the NAC or Mohamed El- Baradei is given no comparable description. In newspapers, the inclusion of any actor in the text is revealing but the way the same actor is positioned in the text is of much more importance. In Richardson's formulation:

News text is structured like an inverted pyramid, whereby the facts/points deemed to be most important are located at the top in the headline, leading down in importance through the story lead, the first paragraph and so on to the bottom. (2004, p.46)

As far as CDA is concerned, Fairclough calls this structure "a scale of presence" in media written text, which for him, is running from 'absent' to 'foregrounded (absent - presupposed- backgrounded foregrounded). Accordingly, the location of the Muslim Brotherhood in the analyzed texts is highlighted and put at the top of the texts, whereas other influential secular groups were excluded and made absent or backgrounded at best in the coverage. This foregrounding of the Muslim Brotherhood as a wellorganized powerful group will subsequently be followed by a forgerounding of this group as well as Islamic law (Sharia) as fearful, undemocratic and as a system which is at odds with the Western modern and democratic ruling.

Generally, the threatening nature of Islam in the coverage of the Egyptian revolution was frequently linked to any discussion of the Islamic group; the 
Muslim Brotherhood. To get a first impression about the best way the Muslim Brotherhood has been portrayed, consider the following passage from one of the Telegraph's editorials:

8) "It will take time to evaluate any new Egyptian government - to discover, for example, whether the participation of the Muslim Brotherhood is sinister, harmless or somewhere in between"( $T$, "Britain's foreign policy needs to be made clear on Egypt", 04 February, 2011)

Such a strong presupposition suggests that being harmless is what can characterize the Muslim Brotherhood at best.

In addition, the naming choice adopted by any newspaper to define people "can have a significant impact in the way they are viewed" (Richardson, 2007, p.49). How the papers name their subjects not only identifies the category they belong to, but it also highlights the "relationship between the namer and the named" (2007, p.49). Accordingly, the fact that the selected papers refer to the Muslim Brotherhood using terms and phrases such as 'banned' (NYT,WP), 'the best organized' (NYT, WP, T), 'fundamentalist' (NYT), 'autocratic' (NYT), 'instigators' $(T)$, and 'ultraconservative' $(G)$ reflect clearly how the Western media wants the Muslim Brotherhood to be viewed, what sort of attitude this media has towards their subject, and the nature of the relationship between the namer (the selected papers) and the named (the Muslim Brotherhood).

To stress the threatening nature of political Islam, the situation in Egypt was, more often than not, compared to Iran and the 1979 revolution. Iran's revolutionary experience is also referred to to highlight fundamentalist Islamism as an outcome of the revolution in Egypt. As early as in its first editorial covering of the Egyptian revolution, The Telegraph wrote that:

9) In Egypt, as in many other Arab countries controlled by autocratic governments, Islamic militants are waiting to exploit any opportunity that comes their way. The Iranian revolution of 1979 began as a secular protest movement against the shah and ended with the establishment of the world's most radical Islamic state. (T, "Egypt needs reform, but not revolution", 27 January, 2011)

Presenting a fundamentalist Islamic control of Egypt as an outcome of the revolution just days after Egyptians took to the street is a strong presupposition that exposes the ideological line of reasoning The $T$ is adopting. Additionally, The $T$ sees that invoking the Iranian revolution would be enough to prove the aforementioned presupposition right, and that fundamentalist Islamists are awaiting opportunities to take over power in all Islamic states. Moreover, the excerpt above suggests an Orientalist view that sees all Islamic parties, states and histories through the same lenses; Islamic nations full of homogenous fundamentalist Islamists that will seize any opportunity to take hold of power. The overall outcome is that, to use Said's words, the "average reader comes to see Islam and fundamentalism as essentially the same thing" (1997, p. xvi).

The same sentiment is expressed by The NYT as it invokes the Iranian 1979 scenario and equates it to the situation in Egypt. This is what The NYT wrote:

10) "The Iranian revolution is seared in our memories. There are no guarantees that Egypt's next government will be as friendly to Washington as this one." $(N Y T$, "Egypt's Latest Constitution" 04 December, 2013)

The excerpt above reveals the everlasting worry the West holds vis-à-vis any possibility of having political Islam ruling a state in the Middle East, because Islam, in Said's formulation, is a lasting trauma for the West (1979). The very idea that an event - which forty years ago -ended with power in Islamists' hands is still seared in the West's memories implies the historical fear and anxiety the West holds towards the religion of Islam.

Significantly, Israel is constantly referred to throughout the coverage of the revolution when political Islam is portrayed as fearful and threatening. It is generally placed as a victim, a long with the West, of any takeover of power by Islamists in Egypt. Traditionally, Orientalist narratives have placed Arabs and Israel in a "simple-minded dichotomy of freedomloving, democratic Israel" on the one hand, "and evil, totalitarian, and terroristic Arabs" on the other (Said, 1978, p.27).

The American and the British media repetitively discuss how Israel and its interests in the Middle East will be affected after losing an ally like Mubarak in Egypt. The selected papers, to a lesser extent The Guardian, stressed an inevitable danger that will follow the ousting of Mubarak if Egypt is governed by Islamic law. A myriad of editorials projected Israel, and the West at large, as a scapegoat of political Islam in the Middle East.

\section{Islamic Ruling: an Antithesis of the West and its Values}

One of the recurrent arguments raised against the Islamic ruling and the Muslim Brotherhood, during the coverage of the revolution, is that Islam and Islamic law are intolerant of non-Muslim minorities, that Islam 
is undemocratic, unmodernized and that it restricts freedoms. Consider, for example, when The WP wrote that:

1) "Its [The Muslim Brotherhood] long-term aim of establishing an Islamic government in Egypt is at odds with what the mostly secular and middle-class demonstrators have been calling for: the democratization and modernization of the country." (WP, "Misconceptions about the Egyptian crisis", 31 January, 2011)

The excerpt shows The $W P^{\prime}$ s positioning of the Muslim Brotherhood as not viable for democratic and modern ruling. It is highlighted as unfeasible to respond to the Egyptian's calls for democratizing and modernizing the country. The question that poses itself here is: has the Muslim Brotherhood or a Muslim government ever had the chance or been elected to rule Egypt, before the writing of the editorial? Put differently, positioning the Muslim Brotherhood practice of Islamic ruling is a mere unfounded allegation since, for example, "commitment to democracy is a serious issue but cannot be gauged by hurling groundless accusations" (El-Ghobashy, 2005).

The same covering patterns persist with the other papers. In one of its editorials, The Telegraph states openly its aggressive identification of Islam and Islamic ruling. Consider the following passage for clarification:

2) Britain knows who it does not want running Egypt: an Islamic regime so fanatically antiWestern that it uses the Suez Canal as a weapon against us, reneges on its peace treaty with Israel and fosters instability in the region. Another thing we do not want is a fundamentalist regime that uses medieval Islamic law to harass its own citizens and terrorise the Christian Coptic minority. ( $T$, “Britain's foreign policy needs to be made clear on Egypt ", 04 February, 2011)

The passage is clearly pregnant with a negative portrayal of Islam and Islamic law. It is a representation that stresses Islam's inferiority, negativity and threat. The threat dimension of Islamic law as shown in the excerpt is assumed to be on many levels: the threat it poses to the West ("uses the Suez Canal as a weapon against us") and ("reneges on its peace treaty with Israel"); the threat it poses to Egypt and the Middle East ("fosters instability in the region"); the threat it poses to the local people ("harass its own citizens"); and the threat it poses to non-Muslim minorities in Egypt ("terrorise the Christian Coptic minority"). Moreover, this short excerpt mirrors evaluative words with demeaning connotations that are abundantly employed to portray Islamic law: it is 'fanatic', 'antiWestern', 'fosters instability', 'fundamentalist', 'harass' Egyptian citizens and 'terrorise' non-Muslim minorities.

The fearful nature of Islam has already been stressed by Neo-Orientalists like Samuel Huntington and Bernard Lewis who were successful in consolidating the Orientalist vision that Islam is a threat to the West (Ismael \& Measor, 2003). Combined with such a negative portrayal is the practice of the dichotomizing 'us' versus 'them', which also confirms the presence of a subjective perspective that creates an 'Othering' process in the coverage which is reflected in the use of the word 'us' in the expressions "uses the Suez Canal as a weapon against us".

In the same vein, The NYT contributes to emphasizing a presupposed inferior nature of Islamic ruling; its incapability to improve Egypt both economically and politically, and its intolerance towards non-Muslim minorities. To illustrate, The NYT wrote that:

3) "Mr. Aboul Fotouh is charismatic and is seen as a pious man, but not an extremist. He was expelled from the Brotherhood last year for advocating a more tolerant and inclusive approach to Islam and Egypt."(NYT, "Egypt's Chaotic Election", 25 April, 2012)

4) In Egypt, President Mohamed Morsi and the Muslim Brotherhood, the Sunni Islamist party from which he hails, have failed to unite the overwhelmingly Sunni country and its Christian and Shiite minorities around a centrist agenda in the post-Mubarak era. Instead, they have solidified ties with Salafist hard-liners in the Islamist camp; derided opponents, including many secularists, as "enemies of Egypt"; and demonized Shiite and Coptic Christian minorities.(NYT, "Dangerous Divisions in the Arab World “, 28 June, 2013)

In the excerpts above, the Muslim Brotherhood is used as a vehicle through which Islam or Islamic ruling is seen with Islamophobic lenses. In excerpt three, Aboul Fotouh, one of the former leaders of the Muslim Brotherhood, is shadowed with a very positive point of view. He is presented as charismatic, pious and unextremist. The fact that he was expelled the previous year from the Muslim Brotherhood, as declared by The $N Y T$, is seemingly a reason for The $N Y T$ to describe him with positive evaluative terms. Furthermore, the group that expells a person, who is pious, charismatic and unexterimist, for "advocating a more tolerant and inclusive approach to Islam" has to be, absolutely, otherwise. In other words, the Muslim Brotherhood is represented as an intolerant group that excludes people with the good personality traits Abou-Al-Fotouh has. It should also be noted here that the excerpt includes 
unfounded argument represented in the omission of relevant information about Aboul Fotouh's exclusion from the Muslim Brotherhood. Relatedly, Egypt Independent, one of the Egyptian local newspapers, had an interview with Abou-Al-Fotouh and reported the real reason behind his expulsion from the group:

(The) former Muslim Brotherhood leader announced his intention to run for president, defying the group's decision not to field any presidential nominee. After weeks of sending unequivocal warnings, the group's Shura Council decided last week to dismiss the 60-year-old doctor from the organization. (June 21, 2011)

The NYT argues that Abu-Al-Fotouh was expelled for "advocating a more tolerant and inclusive approach to Islam and Egypt", while the reason was simply because he did not abide by the decision the Brotherhood outlined apropos the candidacy for the presidency. This is an omission with which the reader is mystified and presented with one unfounded argument that the Muslim Brotherhood is an intolerant group that rejects any moderation in the way Islamic law is practiced. Consequently, such arguments against the Muslim Brotherhood that the Western media keeps marketing remain uncontested.

The intolerant aspect of Islamic ruling is frequently emphasized throughout the selected $N Y T$ s editorials. In excerpt four stated above, The NYT, during Morsi's ruling period in Egypt, positions the Muslim Brotherhood and Mr. Morsi as failing to unite the Sunnis with other minorities such as Christians and the Shiites in one agenda. Likewise, the Islamic group is presented as deriding its opponents and demonizing Shiite and Coptic Christian minorities. With such information, the reader is not given the relevant information on how the deriding of secularists and the demonizing of Christians and the Shiites happened, and hence is left with unanswered questions. This is a technique of omitting crucial information that renders the reader, finally, mystified.

The same patterns were followed when equating Islamic ruling with restricting freedoms as shown in the excerpt below:

5) "Mr. Morsi and his supporters went too far last year in ramming through a Constitution that greatly enhanced the role of Islamic law and restricted freedoms." $(N Y T$, "Egypt's Latest Constitution", 04 December, 2013)

Again, relevant information, if available, such as what freedoms the Islamic ruling is exactly restricting are omitted from the editorial.

The media views elaborated above had been already marketed in the past three centuries to emphasize a negative nature of Islam and Sharia. These views are indicative of the Orientalist logic that was held by classical Orientalists who conceived of Islam as symbolizing "terror, devastation, the demonic, hordes of hated barbarians" (Edward Said, 1979, p.59). Islam is seen by neo-Orientalists as the antithesis of "Western ideas of individualism, liberalism, constitutionalism, human rights equality, liberty, the rule of law, democracy, free markets, the separation of church and state" that have little resonance in many cultures among which is the Islamic culture (Huntington, 1993, p.40).

\section{Islam: Unsolicitous of Women's Well- being}

The subjugation and repression of women, be they Arab, Muslim, or both, by the Muslim males or the Muslim social system is a powerful argumentative move that is usually deployed to disparage the religion of Islam (Richardson, 2004). The New York Times shapes the audience's view on the status of woman in Egypt in the context of the coverage of the revolution and its aftermath (coup and elections). These media typically choose to describe and report about the Egyptian woman, who in fact enjoys many roles in a variety of cultural groups, but within specific contexts; in this case being victimized by other social actors in Egypt. She is portrayed as someone to pity given the fact that she is sexually abused and is denied her rights by Islam, the Muslim Brotherhood or Sharia law. In The NYT we read that:

1) Cairo's Tahrir Square once symbolized the hope Egyptians felt when they overthrew Hosni Mubarak and began building a democracy. But this iconic rallying point for protesters has today also come to symbolize the terror and contempt women increasingly face since the Muslim Brotherhood came to power and the country descended into turmoil. (NYT, "Terror in Tahrir Square", 28 March, 2013)

In this excerpt, The NYT highlights the dramatic change that takes place in Tahrir square, the most reported place in Egypt and the cradle of the revolution that toppled Hosni Mubarak. This quote is a part of the coverage of the cases of sexual harassment and rape that took place in the demonstrations. Tahrir square is reported to be no longer a place of hopes, but rather a terror zone for women. Besides, The NYT links the terrorizing of women to the coming of the Muslim Brotherhood into power. Here, the Muslim Brotherhood is made, therefore, to symbolize women abuse. The Islamists are foregrounded and made involved in this mistreatment of women. Notice the following excerpt for illustration:

2) The scandal is not just that such violence happens. The women are being blamed by 
conservative Islamists for bringing the assaults on themselves. As Adel Abdel Maqsoud Afifi, a police general and lawmaker, said, "Sometimes, a girl contributes 100 percent to her own raping when she puts herself in these conditions." (NYT, "Terror in Tahrir Square", 28 March, 2013)

Here, the Islamists are reported to blame the victim because they hold women responsible for being harrassed and raped. Besides, an emphasis is put on the Islamist's reaction to violence, and is highlighted as more important than the act of violence itself.

The NYT tries to direct the reader's attention to a linkage between women abuse and the coming of Islamists in Egypt while there is no mention of the attackers for example. Conversly, Al Akhbar newspaper, a local paper in Egypt, argues that "there are indications that the practice of sexual harassment originated from the authorities themselves ... In May 2005, the police recruited paid gangs to sexually harass women taking part in marches in downtown Cairo" (2012). Relatedly, Nehad Abu Komsan (2008), head of the Egyptian Center for Women's Rights, argues that sexual harassment in Egypt is a symptom of the country's political oppression; referring to the fact that terrorizing women in demonstrations is a "tear-gas bomb" technique to lessen the existence of women in street demonstrations. All these arguments are not to be found in the American and British media coverage that rather choose to make Islamists' voice apropos the issue salient in the coverage more than anything else.

Eastern woman, uniquely as a victim, is newsworthy for the Western media. This media's focus on the victimization of Arab women is stereotypical because it tends to project them only as passive and oppressed, while disregarding their presence and status in social, economic or political contexts (Ajrouch, 2007). Put differently, The NYT fails to deal with the positive roles women play during the revolution. This successful role will not result in higher sales numbers as it will not serve the discourse that portrays Arab women as oppressed and victims of the alleged Islamic rule.

In many other instances, the Muslim Brotherhood, and Islamists at large, are brought to the context of violating women's rights. Consider these excerpts for illustration:

3) "Critics say the constitution leaves too much room for Islamists to dominate, tramples the rights of minorities like Coptic Christians and is weak on women's rights."(NYT, "Egypt's Flawed Constitutional Vote", 13 December, 2012)
4) "Islamists known as Salafis, who among other noxious beliefs deny women the right to vote." (NYT, “Egypt's Vote”, 01 December, 2011)

5) "The Brotherhood's positions on sharia law, the status of women, censorship, non-Muslim minorities, and on Israel, although modified, must still be worrying." ( $G$, "Islam in Egypt: fear and fantasy", "Egypt: a revolution on the brink of self-destruction”, 05 February, 2011)

6) "The president [Mr. Morsi] has failed to build the inclusive administration he promised, with both Copts and women among the disappointed constituencies." ( $G$, "Egypt: a revolution on the brink of self-destruction", 29 June, 2013)"

In excerpt 3 , in the context of its coverage of the then new Constitutional Declaration issued by President Morsi in 2012, The NYT quoted anonymous critics saying that Morsi's constitution gives chance to Islamists to dominate, violate the rights of coptic christians and does not serve women's right. Once again, the Egyptian woman is presented as a victim; influenced negatively by the Muslim Brotherhood's constitution; and put along with Coptic christians in the same category of those victimized by the Islamists. The very idea of placing Egyptian women with the Chritian minority in Egypt as undergoing the same repression by Islamists would urge Western readers to keep feeling antipathy towards Islam and Islamists as a religion that represses women and tramples the rights of the Christian minority in the Middle East.

Similarly, in excerpt 4, The NYT refers to another minority of Islamists; the Salafis, and presents them as denying women the right to vote. The Arab women are thus represented as politically immature and unable to make their political choices, and Islamists are portrayed as supporters of this violation. Additionally, The NYT presupposes that the Salafis have many other noxious beliefs, one of which is denying women the right to vote. Here, what Huckin (2002) calls 'presuppositional silence' is put into practice in the sense that the writer does not state what he is apparently assuming.

Conversely, the West's treatment of women's status and rights is reported to be the opposite of all that the Islamists did or say apropos the same issue. The West is, once again, presented as 'what the East is not'. Consider the following for illustration:

7) "This month, when a United Nations conference adopted guidelines for ending violence against women, the Brotherhood condemned the statement, saying it would undermine Islamic ethics and lead to the disintegration of society." $(N Y T$, “Terror in Tahrir Square”, 28 March, 2013) 
Three main ideas are stated in the above mentioned excerpt: 1) the West is making effort to stop women's misery in Egypt, 2) these efforts are condemned by the Muslim Brotherhood and 3) the Muslim Brotherhood say that the West's guidelines for ending violence against women will undermine Islamic ethics and disintegrate society. This statement is written by $T$ The $N Y T$ immediately after its coverage of the sexual attacks and rapes in Tahrir square. The West, by the name of the United Nations, is shown as working on eradicating violence against Arab women. Reporting about the United nations guidelines for ending violence against women is implicitly considered the West's reaction to the Arab barbarity and savageness the Egyptian woman is suseptible to, a 'moral imperative' to save the Arab women from torture. This Western duty, as implicitly suggested by $T h e N Y T$, is according to Spivak, a case of "white men saving brown women from brown men" (1999, p. 287). This duty that is considered by the Muslim brotherhood, as assumed by The NYT, to be against Islamic ethics is significant. It implies that the Islamists are finally portrayed as soliciting and advocating violence against women.

The representation of the Egyptian women in the editorials covering the Egyptian revolution reflects Orientalist tropes. It echoes the medieval classical representation of Muslim woman as victimized and oppressed by the alleged Islamic rule. Such representation makes women visible solely in problematic contexts: being victimized, oppressed, and denied basic rights by Islamists and Islamic law. Meanwhile, the West is represented to correct the mistakes of the Easterners by saving the Arab women from the Muslim male-chauvinist society.

\section{CONCLUSION}

This study uncovers the strategies and the ideological lenses through which the revolution and its aftermath in Egypt are consequently framed. The focus has always been to locate Orientalist modes of thought in the way the Western editors make sense of the subjects being reported. Accordingly, CDA traces a rhetoric that is stereotypical at best. It shows how the selected media highlights Islam/political Islam as the antithesis of the modern democratic Western ruling, how they emphasize it as restrictive of human rights, and how they project it as threatening to the stability in the Middle East (the stability that would serve uniquely the Western icon, Israel). Through the analysis of presupposition, foregrounding, backgrounding, omission, and mystification in the selected text, Islam and Islamists are found to be framed in a way that reflects the images inherent in Orientalist metaphorical conceptualizations that see the East as the extreme Antithesis of the West and its Values.

\section{REFERENCES}

1. Abdalla, M. and Rane, H. (2007). The Impact of Media Representations on the understanding of Islam and Attitudes toward Muslims in Queensland. Retrieved https://core.ac.uk/reader/196153350

from

2. Abul Komsan, N. (2008). Clouds in Egypt's Sky: Sexual Harassment: From Verbal Harassment to Rape. Retrieved from https://www.shorturl.at/dosvy

3. Abushouk, A. (2014).Time and Newsweek's Coverage of the Arab Uprisings in 2011: A Content Analysis Survey. Asian Review of World Histories, 2(1), 81-104

4. Ajrouch, K, J. (2007). Global contexts and the veil: Muslim integration in the United States and France. Sociology of Religion, 68(3), 321-325.

5. Akbarzadeh, S., \& Smith, B. (2005). The representation of Islam and Muslims in the media. Sydney: Monash University Press.

6. Altwaiji, M. (2014). Neo-Orientalism and the neoimperialism thesis: Post-9/11 US and Arab World relationship. Arab Studies Quarterly, 36(4), pp. 313-323.

7. Arti, S. (2007). The evolution of Hollywood's representation of Arabs before 9/11: the relationship between political events and the notion of 'Otherness'. Journal of the MeCCSA Postgraduate Network, 1(2), 1-20.

8. Azeez, V. (2018). Influence of newspaper editorials on the policies of Lagos state government. Retrieved from https://www.academia.edu/9349387/INFLUENCE_ OF NEWSPAPER

_EDITORIALS_ON_THE_POLICIES_OF_LAGOS _STATE_GOVERNMENT

9. Berelson, B. (1952). Content analysis in communication research. New York: Hafner.

10. Chouliaraki, L. and Fairclough, N. (2010). 'Critical discourse analysis in organizational studies: towards an integrationist methodology'. Journal of Management Studies, 47, 1213-8.

11. Conte, W. (2001, September 28). British media portrayals of Muslims in the wake of the September 11 attacks. Retrieved from https://cmsw.mit.edu/reconstructions/communicatio ns/ukmuslims.html

12. Dabashi, H. (2012a). The Arab Spring: The End of Postcolonialism. London: Zed Books.

13. Edward, B. (2001). Yankee Pashas and Buried Women Containing Abundance in 1950's Hollywood Orientalism. Film \& History. 31(2), 13 24.

14. El-Ghobashy, M. (2005). The metamorphosis of the Egyptian Muslim Brothers. International Journal of Middle East Studies, 37(3), 373-395. DOI: 10.1017.S0020743805373041. Retrieved from 
https://www.cambridge.org/core/journals/internatio nal-journal-of-middle-east-

studies/article/metamorphosis-of-the-egyptian-

muslim-

brothers/144AAOB05B728206A0A2BD9F371D473

$D$

15. El-Mahdi, R. (2011). Orientalising the Egyptian Uprising. Retrieved from https://www.jadaliyya.com/Details/23882

16. Fairclough, N. (1989). Language and power. New York: Longman

17. Fairclough, N. (1992a). Discourse and Social Change. Cambridge: Polity Press.

18. Fairclough, N. (1995a). Critical Discourse Analysis. London: Longman.

19. Fairclough, N., \& Wodak, R.(1997). Critical Discourse Analysis. In T. A. van Dijk (Ed.), Discourse as Social Interaction (pp. 258-284). London: Sage.

20. Fairclough, N. (2001b). Language and Power (2nd ed.). London: Longman.

21. Fairclough, N. (2003). Analysing Discourse: Textual Analysis for Social Research.

22. Huckin, T. (2002). Textual silence and the discourse of homelessness. Discourse and Society, 13(3), 347-372.

23. Ismael, T.Y. \& Measor, J. (2003). Racism and the North American Media Following 11 September: The Canadian Setting. Arab Studies Quarterly, 25 (1-2), 101-136. Retrieved from: https://caoshea.files.wordpress.com/2010/04/racis $m$-and-the-north-american-media-following-11sept-canada.pdf

24. Khouri, R.G. (2011, August 17). Drop the Orientalist term 'Arab Spring'. The Daily Star Retrieved from http://www.dailystar.com.lb/Opinion/Columnist/20 11/Aug-17/146410-drop-the-orientalist-term-arabspring.ashx

25. Mandaville, P. (2013). Islam and Exceptionalism in American Political Discourse. Political Science \& Politics, 46, 235-239.

26. News24. (2018). A timeline of key events in Egypt since the 2011 uprising. Retrieved from https://www.news24.com/Africa/News/a-timelineof-key-events-in-egypt-since-the-2011-uprising20180326

27. Nurullah, A. S., (2010). Portrayal of Muslims in the media: "24" and the 'Othering' process. International Journal of Human Sciences. 7(1), 1021-1046.

28. Ould Brahim, E. (2012). Arab Revolutions: Orientalism Reconsidered. Al Jazeera Centre for Studies.

29. Poole, E. (2002). Reporting Islam: Media representations of British Muslims. London: I.B. Tauris.

30. Richardson, J. E. (2004). (Mis)Representing Islam: The racism and rhetoric of British broadsheet newspapers. Amsterdam: John Benjamins Publishing Co.

31. Richardson, J.E. (2007). Analysing Newspapers: An Approach from Critical Discourse Analysis. New York: Macmillan.

32. Rogers, T. (2018). The Difference Between Broadsheet and Tabloid Newspapers. Retrieved from https://www.thoughtco.com/broadsheet-andtabloid-newspapers-2074248

33. Rushworth, P. (2012) Orientalism Revisited. Retrieved from http://www. http://albab.com/articles-section/orientalism-revisited

34. Saeed, A. (2007a). Media, racism and Islamophobia: the representation of Islam and Muslims in the media. Sociology Compass, 1(2), 433-462. doi:10.1111/j.1751-9020.2007.00039.x

35. Said, E. W. (1978). Orientalism. New York: Vintage Books.

36. Said, E. W. (1981). Covering Islam: How the media and the experts determine how we see the rest of the world. London and New York: Routledge.

37. Said, E. W. (1997). Covering Islam: How the media and the experts determine how we see the rest of the world (Revised edition). New York: Vintage Books.

38. Said, E. W. (2003). Orientalism. New York: Vintage Books

39. Shaheen, J. G. (2003). Reel bad Arabs: How Hollywood vilifies a people. Gloucestershire: Arris Books.

40. Shoemaker, P. J. (1991). Gatekeeping. London: Sage.

41. Telci, I. (2011). Positions of social actors in the Egyptian revolution: a micro level analysis. Journal of Academic Inquiries, 6(2), 171-200. Retrieved from: https://dergipark.org.tr/download/article-file/17779

42. Van Dijk, T. A. (1988). News analysis: Case studies of international and national news in the press. Hillsdale, New Jersey, Hove and London: Lawrence Erlbaum Associates.

43. Van Dijk, T. (1991). Racism and the Press. London: Sage.

44. Van Dijk, T. A. (1997a). 'The study of discourse'. In Van Dijk, T. A. (Ed.), Discourse as Structure and Process: A Multidisciplinary Introduction, Vol. 1. London: Sage. 